\title{
A framework for considering ecological interactions for common non-timber forest product species: a case study of mountain date palm (Phoenix loureiroi Kunth) leaf harvest in South India
}

Lisa Mandle ${ }^{1,2,5^{*}}$, Tamara Ticktin ${ }^{1,2}$, Snehlata Nath ${ }^{3}$, Siddappa Setty ${ }^{4}$ and Anita Varghese ${ }^{1,3}$

\begin{abstract}
Introduction: Many economically important non-timber forest products (NTFPs) come from widespread and common plant species. Harvest of these species often is assumed to be sustainable due to their commonness. However, because of the ecological roles of common species, harvest may affect and be affected by ecological interactions at broader scales, which are rarely considered when evaluating the sustainability of harvest. We use a case study of the mountain date palm (Phoenix loureiroi Kunth), harvested in South India to produce brooms, to present a conceptual framework illustrating how intensive harvest of a common species interacts with other anthropogenic management practices, plant-animal interactions and surrounding environmental conditions.

Methods: We apply this framework to understanding the impacts of mountain date palm harvest in the southern Western Ghats regions of the Indian states of Tamil Nadu and Karnataka. We integrate data on the extent and levels of commercial harvest, local management practices, the ecological context in which harvest occurs, and research on harvest effects. We use this information to document the intensity and extent of mountain date palm harvest in the study area, identify the ecological implications of harvest, and demonstrate how a framework that considers harvest in the context of ecological communities and ecosystems is important for assessing the impacts of harvest of common NTFP species.

Results: We show that mountain date palm leaves are heavily harvested from natural areas in the southern Western Ghats but that harvest levels have declined in recent years. Mountain date palm management and harvest occur within a network of ecological interactions, linking human activities to population-, community-, and ecosystem-level processes. We demonstrate that understanding the effects of return interval of anthropogenic fire, herbivory by wild animals and livestock, as well as the light environment in which harvest occurs are critical to assessing the sustainability of mountain date palm harvest.

(Continued on next page)
\end{abstract}

\footnotetext{
* Correspondence: lisa.mandle@gmail.com

'Botany Department, University of Hawai'i at Mānoa, Mānoa, Hawai'i, USA

${ }^{2}$ Ecology, Evolution and Conservation Biology Program, University of Hawai'i

at Mānoa, Mānoa, Hawai'i, USA

Full list of author information is available at the end of the article
} 
(Continued from previous page)

Conclusions: By considering mountain date palm leaf harvest in the context of ecological interactions at multiple scales, our findings show that sustainability cannot be assessed only from a population-level perspective. This general framework highlights the need to incorporate ecosystem- and community-level properties and processes more frequently into assessments of the sustainability of NTFP harvest-especially for widespread and common species - to ensure that their important economic and ecological roles are maintained.

Keywords: Non-timber forest product (NTFP); Western Ghats; Savanna woodland; Resource management; Plant-animal interactions; Fire; Herbivory

\section{Introduction}

Harvest of non-timber forest products (NTFPs) has been promoted as an opportunity to both enhance local livelihoods and contribute to biodiversity conservation (Leisher et al. 2010). At the same time, the effectiveness of NTFP harvest at achieving these goals has been criticized (Belcher and Schreckenberg 2007), and over-harvest is considered a major threat to plant diversity (Brummit and Bachman 2010). This contrast between goals and outcomes illustrates the need to improve our understanding of the circumstances in which NTFP harvest can make a meaningful contribution to local livelihoods without having negative environmental consequences.

Widespread and abundant non-timber forest product (NTFP) species have a high potential to be harvested sustainably (Cunningham 2001). Because of their high levels of biomass, however, these same species are likely to influence ecosystem processes and have significant interactions with other components of the ecological community, interactions which may be altered by harvest (Gaston and Fuller 2008; Gaston 2010). If promoting NTFP harvest is meant to contribute both to local livelihoods and to the conservation of ecosystems, it is critical to assess the sustainability of harvest from an ecosystem perspective, especially for common species.

Many heavily harvested NTFP species are locally abundant and/or widely distributed. For example, several species of shrubs, grasses, and reeds that are harvested to make hand brooms in South Africa are locally dominant, respond positively to disturbances such as grazing or fire, or are otherwise considered "weedy" (Shackleton 2005). Similarly, the multi-use palm Phoenix reclinata Jacq. is widely distributed across temperate and tropical Africa (Barrow 1998) and can be one of the most abundant species where it occurs (Kinnaird 1992). Studies of the ecological impacts of harvest of these kinds of common species are limited compared to studies that focus on species perceived to be rare or in decline, often under the expectation that abundant and disturbance-tolerant species have a high potential for sustainable harvest (Reid 2005; Shackleton 2005; Shackleton et al. 2009).
While there may be a high potential for sustainable harvest of common species from a population-level perspective, high levels of harvest are particularly likely to alter ecological interactions and ecosystem processes. A plant species' abundance is an important determinant of its influence on ecosystem structure and function, with more abundant species generally having a greater effect than rare species (Grime 1998). An emphasis in the NTFP literature on studying the population dynamics of rare and declining species could lead to the biased conclusion that ecological interactions and ecosystem-level effects resulting from harvest are generally unimportant. This difference in the ecological role of abundant species means that while high levels of fruit or seed harvest can have negligible impacts on populations of common, long-lived, clonally reproducing plant species (Ticktin 2004), harvest may still negatively affect frugivores, including birds (Moegenburg and Levey 2003) and primates (Kinnaird 1992) that rely on that fruit for food. When harvest involves removing large amounts of biomass from an ecosystem, this may also alter nutrient cycles (O'Hara 1999).

Despite growing recognition that NTFP harvest affects and is affected by management practices and ecological interactions at multiple levels, these interactions are rarely studied above the population level (Ticktin 2004). Understanding the larger ecological context in which harvest of common NTFP species occurs is necessary to devise appropriate management plans to maintain both the economic and ecological roles of such species. If harvest occurs without an awareness of the many ecological interactions that it can affect and be affected by, the cascading effects of harvest could have large, unanticipated consequences both for ecological processes and the people who rely on them (Estes et al. 2011).

We use a case study of mountain date palm (Phoenix loureiroi Kunth, formerly $P$. humilis) to present a conceptual framework for considering the broad ecological consequences of harvesting common NTFP species. Mountain date palm is a widespread and common species, heavily harvested for its leaves in India's southern Western Ghats. Information about the ecology, current 
harvesting intensities, and management practices of mountain date palm is not available. We integrate data on the extent and levels of commercial harvest, local management practices, the ecological context in which harvest occurs, and research on harvest effects to (1) document the intensity and extent of mountain date palm harvest in the southern Western Ghats, (2) identify the ecological implications of harvest, and (3) demonstrate how a framework that considers harvest in the context of ecological communities and ecosystems is important for assessing the impacts of harvest of common NTFP species.

\section{Methods}

\section{Study species}

Mountain date palm is widely distributed across subHimalayan Asia, from India through southern China into Taiwan and the Philippines (Barrow 1998). It occurs in the understory of forests and more open grasslands and scrublands, including disturbed areas. In addition to being widespread, mountain date palm is also common where it occurs, reaching densities of up to 14.0 individual ramets per $\mathrm{m}^{2}$ (mean: 4.5 ramets per $\mathrm{m}^{2}$ ) within the populations we studied. Although it can reach heights of up to $5 \mathrm{~m}$, it often remains short-stemmed and shrubby, reproducing vegetatively, in dry habitats.

In South India, mountain date palm is known locally in Tamil as seemar or eecham and in Kannada as porake or echalu, and its leaves have been commercially harvested for the manufacture of brooms since at least the mid-20th century (Sundararaj and Balasubramanyam 1986). High levels of harvest have led to concerns that this species could become rare (Padmanabhan and Sudhersan 1988). Mountain date palm continues to be harvested in large quantities; where it occurs, it can be one of the most harvested NTFP in terms of biomass (Nath 2000; Shaanker et al. 2004). Overall, NTFPs provide an important source of income-sometimes upwards of $50 \%$ of household income-to local communities in the southern Western Ghats, especially those living in and around forest areas (Shaanker et al. 2004). Harvest of mountain date palm leaves in particular can contribute nearly $25 \%$ of household income (Biswal 2009).

\section{Study area}

Our study focuses on the southern part of the Western Ghats biodiversity hotspot (Myers et al. 2000), including Tamil Nadu and Karnataka (Figure 1). Here, mountain date palm occurs primarily in grasslands, savannas, and dry deciduous forests on rocky hill slopes. Commercial harvest of mountain date palm leaves by local indigenous communities takes place in Reserve Forests managed by the Forest Department of India. Mountain date palm is also found in protected areas where commercial harvest is commonly prohibited. Indigenous (adivasi) communities involved in mountain date palm harvest in the study area include Irula, Kurumba, and Soliga. These communities' livelihoods are based primarily on subsistence agriculture and NTFP harvest, as well as wage labor [see Keystone Foundation (2007) and Shaanker et al. (2004) for additional details].

In Tamil Nadu, NTFP harvest is managed through Village Forest Committees (VFCs) formed through the Joint Forest Management process in the 1980s. Each VFC has an area demarcated where commercial harvest is allowed during a particular season. If the VFC has adequate funds, it pays harvesters to collect leaves and then auctions the leaves to the highest bidder among registered forest contractors. If the VFC lacks funds to pay harvesters up front, it auctions the collection rights to a contractor and then uses an advance from the contractor to pay wages to harvesters. In Karnataka, harvest is run by co-operative societies called LAMPS (Large Scale Adivasi Multi Purpose Societies), which organize the collection and sale of NTFPs in a similar manner.

\section{Data collection}

To obtain a holistic view of mountain date palm leaf harvest in the region, we bring together data from multiple sources. These include the following: (1) Records from five VFCs (Tamil Nadu) and three LAMPS (Karnataka) on the amount of mountain date palm leaves purchased and price paid to harvesters. These records include harvest in and around the Sathyamangalam Reserve Forest in Tamil Nadu, the Biligri Rangaswamy Temple Wildlife Sanctuary (BRT, now a tiger reserve), and the Male Mahadeshwara Hills Reserve Forest (MM Hills) in Karnataka (Figure 1). (2) Semi-structured interviews conducted with 13 individual harvesters from two sites in 2009 and discussions with two harvester groups from two additional sites in 2011, covering harvest practices and the land-management context in which harvest occurs. These interviews were conducted in local languages (Tamil, Kannada, Irula, and Soliga) with the help of interpreters. We obtained informed consent from interviewees and Human Subjects Review Board exemption. (3) Observations of harvesting and marketing practices and perceptions based on our (SN, AV, and SS) combined more than 50 years of work in collaboration with indigenous communities on conservation and livelihoods in the Western Ghats. (4) Published documents, as well as gray literature on the subject of NTFP harvest in the Western Ghats. (5) Results of experimental and observational ecological studies of mountain date palm demography from 2009-2011 (Mandle 2012; Mandle and Ticktin 2012).

\section{Calculating the extent of harvest}

Levels of harvest were recorded in terms of number of broom bundles in Karnataka and metric tonnes of leaves 


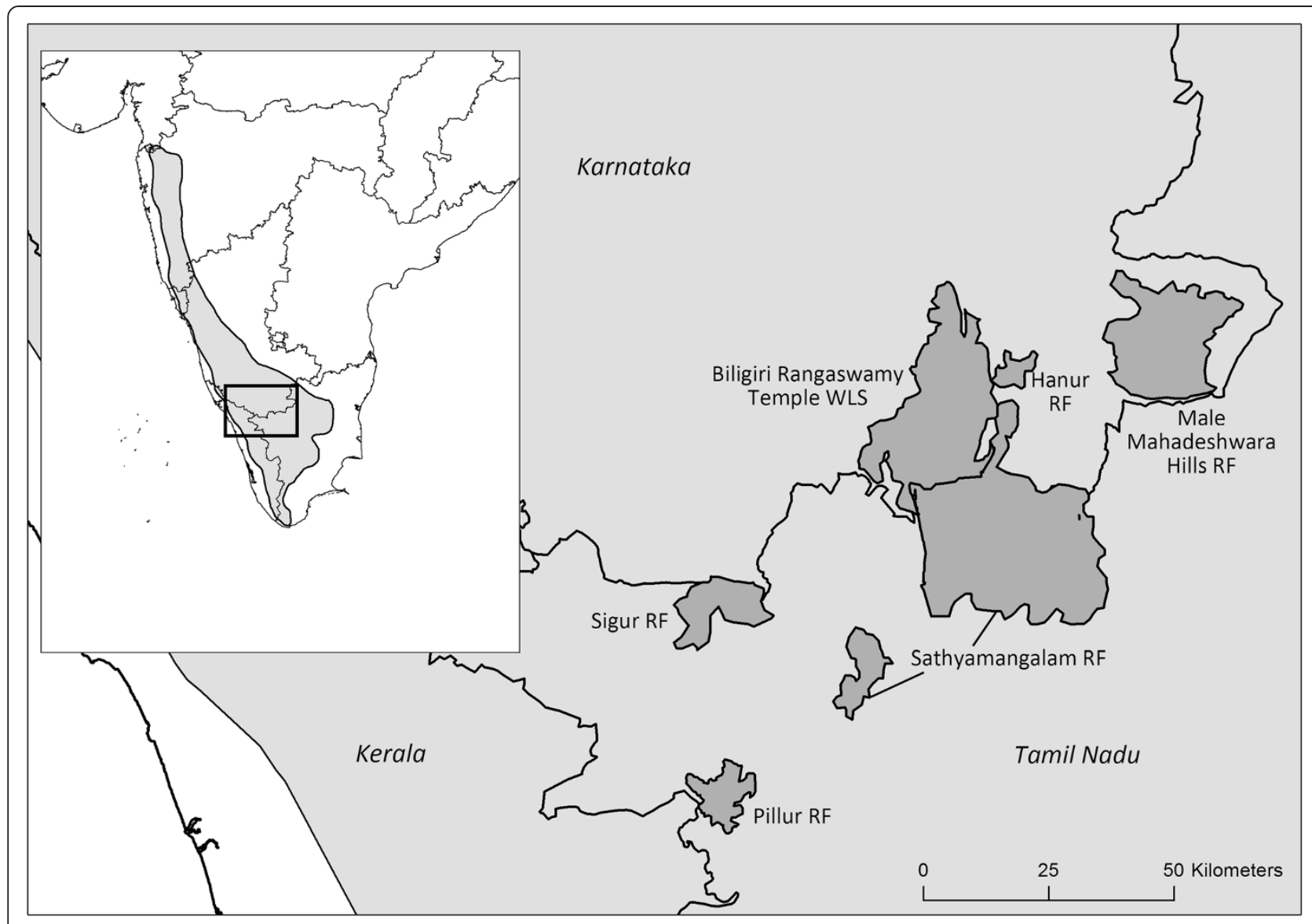

Figure 1 Areas of commercial harvest for which mountain date palm harvesting practices and/or harvesting levels are documented in this study are shown in dark gray. Harvest occurs in and around the Reserve Forests (RF) and formerly occurred in the Wildlife Sanctuary (WLS). The Western Ghats Biodiversity Hotspot is shown in light gray.

harvested in Tamil Nadu. We converted broom bundles to metric tonnes using measures of palm leaves per kilogram and palm leaves per broom bundle (Keystone Foundation unpublished data). To scale harvest impacts to the population and community level, we also estimated the number of leaves harvested, number of plants harvested, and area under harvest using 95\% confidence intervals for mean leaves harvested per palm and per hectare from eight palm populations in areas with commercial harvest across the study area from 2009 to 2011 (Mandle 2012).

\section{Results and discussion}

\section{Extent of and trends in mountain date palm harvest levels}

Mountain date palm is both widely and heavily harvested across the southern Western Ghats. Mountain date palm leaves are currently harvested commercially from numerous Reserve Forests. During the 2009-2010 harvest year, for the eight locations for which we have data, a total of 328 metric tonnes were harvested through the five VFCs in Tamil Nadu and an additional 29 metric tonnes were harvested from one LAMPS in Karnataka. The documented harvest comprises an estimated 23 million leaves (95\% confidence interval: $21-25$ million), from 7.5 million plants (95\% confidence interval: 6.5-8.6 million). Based on our observational studies (Mandle 2012), an average of 3.1 leaves out of 4.3 total leaves are taken from each harvested palm. These harvested leaves come from hundreds of hectares of palm habitat (95\% confidence interval: $300-1,500$ ).

The quantities of harvested mountain date palm leaves have declined in recent years in all areas (Figure 2a), while the price per kilogram has increased (Figure 2b). In the Tamil Nadu sites, levels of harvest declined between 2007 and 2009 in four out of five areas. During this time, the mass of harvested leaves declined $18.8 \%$ in the region as a whole, while the price paid per kilogram increased $16.7 \%$, leading to an overall decline of $5.3 \%$ in the value of leaves harvested (Figure 2c). The price increase is comparable to the overall inflation rate in India over the same time period (International Monetary 

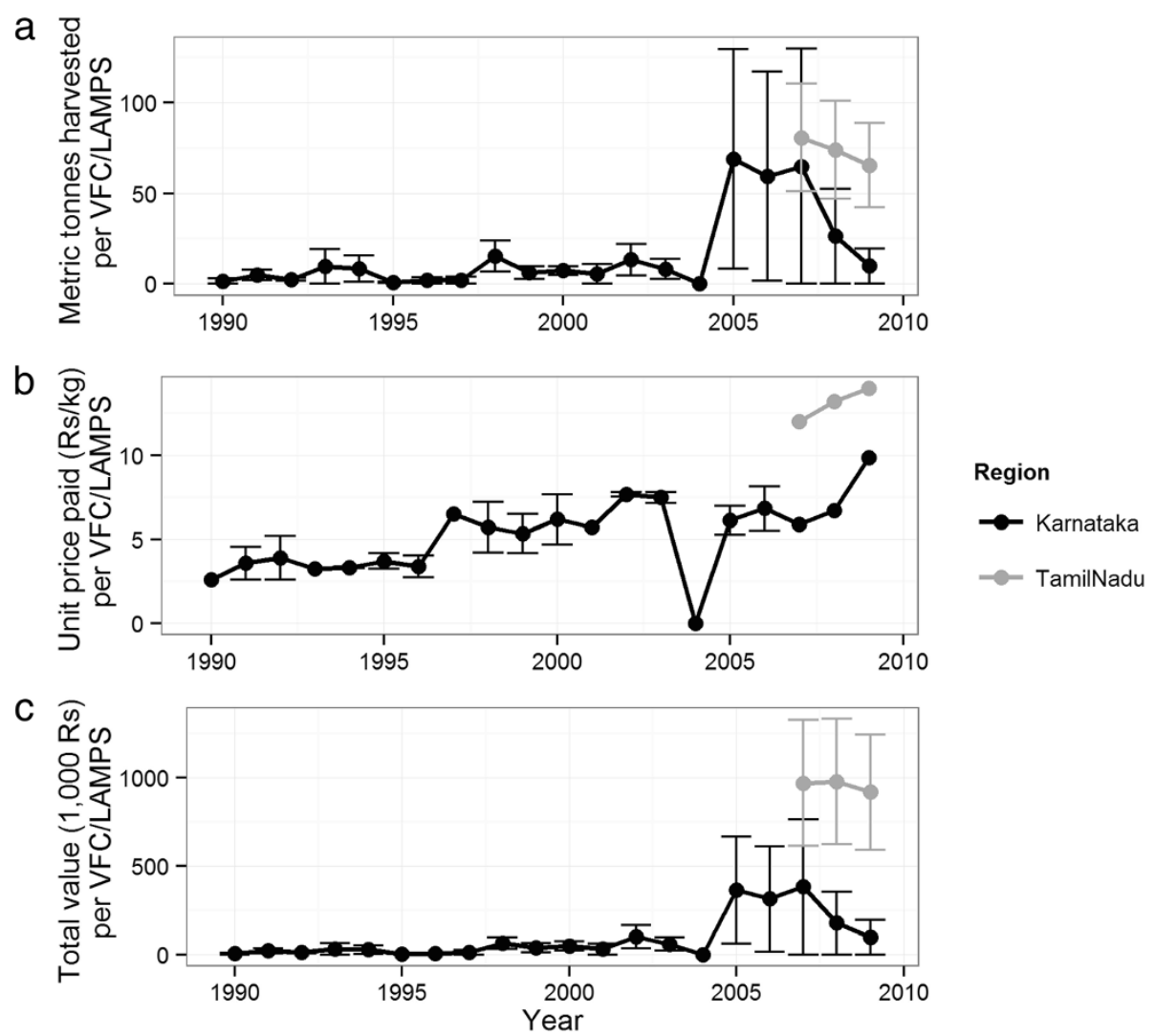

Figure 2 Mass (a), unit price (b), and total value (c) of mountain date palm leaves harvested from VFCs (Village Forest Committees) and LAMPS (Large Scale Adivasi Multi Purpose Societies) at eight sites. The mean and standard error are shown by state ( $n=3$ for Karnataka and $n=5$ for Tamil Nadu). Harvest records were available from 1990 to 2009 for Karnataka and from 2007 to 2009 for Tamil Nadu.

Fund 2012), but this rate largely does not account for items like NTFPs that are traded in the informal economy. The same pattern of decreasing harvest with increasing prices appears in the Hasanur Range (within Sathyamangalam forests of Tamil Nadu) over the past 5 years, while harvest has ceased in two of three Karnataka areas. Commercial harvest occurred previously in BRT but was banned by the Forest Department after 2004. With the passage of India's Forest Rights Act (FRA), communities in BRT are in the process of obtaining the right to resume harvest. As of October 2011, 25 of 62 gram sabhas (village assemblies) had obtained NTFP harvest rights under the community forest rights provision of the FRA. It is the first case in the country in which NTFP collection and conservation rights have been awarded in a protected area.

Overall, the harvesters interviewed generally did not perceive a change in availability of palm leaves, or believed that there are more available for harvest now than in the past. However, 3 of 13 harvesters interviewed individually reported that there was decreased leaf availability due to the invasive plant Lantana camara L. shading out palms (in the Sathyamangalam region of
Tamil Nadu) and from increased elephant herbivory (in the Sigur region of Tamil Nadu).

While some might see recent declining levels of palm leaf harvest as an indicator of over-exploitation, this is not the only possible driver of the pattern we observed. Reduced leaf harvest could occur if harvesters are choosing to pursue other economic opportunities, such as wage labor. Opportunities for wage labor have been increasing. For example, with the passage of the Mahatma Gandhi National Rural Employment Guarantee Act (NREGA 2005), which was implemented starting in 2006, rural households are assured 100 days of wage labor per year (NREGA 2005). Mountain date palm leaf harvest occurs primarily in the first half of the year, during the agricultural off season, which is when people are likely to be taking advantage of NREGA. Levels of harvest may also be declining due to the lack of organization for collection and trade of NTFPs through VFCs, which vary in levels of competency (Keystone Foundation 2009). Harvesters are less likely to collect leaves if it is uncertain they will be paid for their efforts. Finally, reduced availability of leaves due to increased abundance of the invasive Lantana camara or other environmental changes could explain the 
declining levels of harvest in some areas. The spread of Lantana camara in BRT has reduced the diversity and density of native woody species (Sundaram and Hiremath 2012) and could be impacting mountain date palm as well. Further study is needed to distinguish among these multiple explanations for declining harvest. Nonetheless, this highlights the difficulty of inferring ecological processes from economic data for non-timber forest products.

\section{Mountain date palm harvesting practices and management}

Commercial palm leaf harvest generally occurs during the dry season and agricultural off-season during the first half of the year, though harvesters report that they collect leaves for personal use as needed throughout the year. Leaves are only cut if they are at least an arm's length; shorter leaves cannot be used for brooms. Generally, all leaves meeting the size requirement that are not damaged or senescing are harvested from an individual plant. This sometimes includes all fully emerged leaves. People also eat the palm's apical shoots when plants resprout after fire and at the beginning of the rainy season.

Fire is the primary tool used to manage mountain date palm populations for harvest. Harvesters in some areas report setting ground fires to remove palm leaves that are too old and damaged to be harvested, while promoting the growth of new leaves (see also Roveta 2008). Harvesters also benefit from low-intensity ground fires set by livestock herders to promote fodder or from accidental fires that spread. Harvesters report that the quality of palm leaves is higher after ground fires.

Apart from the use of fire, harvesters did not report any other management activities deliberately used to increase leaf production or enhance palm populations. Competing vegetation is not removed (except to create access paths) and no efforts are made to propagate palms through seeds. Harvesters considered it unnecessary to attempt to propagate palms in harvested areas because of mountain date palm's natural abundance.

\section{Leaf harvest and ecological interactions}

Integration of local knowledge and ecological studies suggests multiple ecological pathways that have the potential to affect the sustainability of mountain date palm leaf harvest. We illustrate some of these possible pathways-which are likely to be relevant to other common NTFP species-in a conceptual diagram (Figure 3). Fire is a common management tool for many NTFPs, including palms (Blancas et al. 2010). Despite this, studies of NTFPs that explicitly consider the relationships among fire, harvest, and sustainability are rare (but see Varghese and Ticktin 2008; Schmidt 2011). In the case of the mountain date palm, fire increases individual mortality (Mandle and Ticktin 2012). Although surviving palm individuals grow more after fire (Mandle and Ticktin 2012), the intensity of leaf harvest as well as the intensity of grazing by both domestic livestock and wild animals can increase following fire (Mandle 2012). Models of palm population dynamics parameterized with empirical

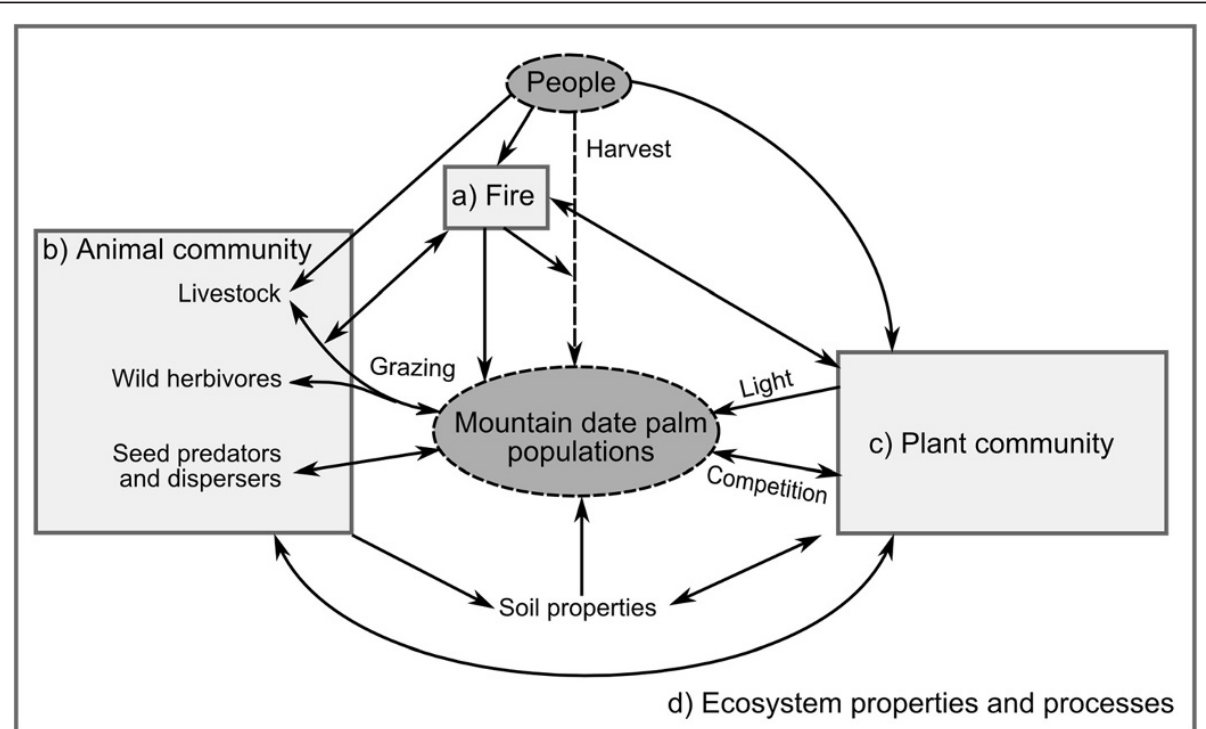

Figure 3 Assessing the sustainability of mountain date palm harvest requires going beyond the direct relationship between people and harvested palm populations (dashed lines) to consider multiple ecological interactions. Sustainability of harvest is mediated by the use of fire through multiple pathways (a). Furthermore, harvest both affects and is affected by the surrounding animal (b) and plant (c) communities, as well as the ecosystem-level context in which harvest occurs (d). The management activities of people additionally depend on socio-economic context. 
data show that populations can withstand low levels of harvest and grazing, but high intensities of both activities can drive declines in population growth rates (Mandle 2012). The decrease in population growth rates with heavy harvest results from reduced individual rates of growth and reduced seedling regeneration (Mandle 2012; Mandle and Ticktin 2012).

Because people prefer to harvest in areas with recent fire, and because grazing on palms increases after fire, the sustainability of harvest of this species cannot be assessed without understanding the role of fire (Figure 3a). Increased grazing after fire has also been documented in many grassland and savanna ecosystems (Fuhlendorf et al. 2009). The impacts of fire and the fire-grazing interaction on the potential for sustainable harvest should be considered for any NTFP species occurring in areas with frequent fire.

Results from multiple sources show that mountain date palm is a resource shared by people and wildlife. In the case of the mountain date palm, this includes several species of conservation concern (IUCN 2011) including the Asian elephant (Elephas maximus, endangered), as well sambar deer (Rusa unicolor, vulnerable), gaur (Bos gaurus, vulnerable), and sloth bear (Melursus ursinus, vulnerable). Based on our interviews with harvesters as well as published literature, elephants eat the fruit and uproot whole plants (Sukumar 1990). Harvesters report that palm leaves may also be grazed by wild ungulates, as well as cattle, though the palm is not a preferred food source. Interviews with harvesters revealed a number of additional palm-animal interactions: porcupines dig up and consume underground parts, birds and bear eatand disperse-fruit, and seeds are consumed by rodents. Though the pollination system of mountain date palm is not known, its flowers are visited by insects, especially beetles (Barrow 1998).

The plant-animal interactions between a harvested plant species and its herbivores, pollinators, and dispersers must be kept in mind when considering sustainability of harvest (Figure 3b). Harvesting levels that can be sustained over time from a human-plant perspective could have impacts on wildlife if that plant is a shared resource. For example, in the case of the mountain date palm, leaf harvest reduces rates of flowering and therefore reduces fruit production (Mandle 2012). Because the palm reproduces primarily by vegetative reproduction, this may have a small effect on mountain date palm populations but could have negative consequences for animals that rely on palm fruit for food. In addition, harvest levels that have negligible effects in one context may be unsustainable under a different set of conditions. For example, the same level of leaf harvest might have a negative effect on fruigvore populations when alternative food sources are rare but not when they are plentiful. In the case of mountain date palm, our demographic models show that lower intensities of harvest are likely to be sustainable at the level of palm populations when harvest cooccurs with ungulate herbivory as compared to without (Mandle 2012).

\section{Harvest in a multi-use landscape}

Our interviews and observations reveal that mountain date palm leaf harvest is carried out in areas that are managed by local communities for multiple purposes. Palm leaf harvest frequently occurs along with the harvest of other NTFPs, fuel wood collection, and livestock grazing. The land management context in which NTFP harvest occurs has the potential to impact palm populations indirectly by altering light availability, soil properties, and competitive relationships (Figure 3c, d). The impacts of these factors have been assessed in relatively few instances (e.g., Endress et al. 2004; Ticktin and Nantel 2004). In the case of mountain date palm, we found that more open canopies are associated with higher levels of flowering and fruiting (Mandle and Ticktin 2012). This matches trends found for other understory species (Cunningham 1997; Anten et al. 2003; Ticktin and Nantel 2004), suggesting that the potential for sustainable harvest may be greater in areas with more understory light availability. In addition, activities that create more open canopies-such as fuel wood collection and fire-might increase the potential for sustainable harvest of understory species but have negative effects on other species (Shankar et al. 1998; Davidar et al. 2010). Understanding the impacts of anthropogenic activities that co-occur with NTFP harvest is critical to sustainable management of harvested species and the ecosystems in which they occur.

\section{Conclusions}

Like many economically important NTFPs, mountain date palm is a widespread and common species. Palm leaf harvest generally has a high potential for sustainability from a population-level perspective (Zuidema et al. 2007; Schmidt et al. 2011). While these characteristics would suggest that leaf harvest is unlikely to threaten the species, its prevalence and the extent of harvest means that it is probable that harvest both impacts and is impacted by larger community- and ecosystem-level processes. Common species have rarely been a priority for conservation efforts (Gaston and Fuller 2008; Gaston 2010). Similarly, harvest of many NTFPs is presumed to be sustainable on the basis of their abundance, without any ecological assessment. In the case of mountain date palm and other common, harvested species, there is a need to establish monitoring before they decline, for the sake of maintaining both their larger ecological role and their economic value to harvesters. 
Viewed within a framework of ecological interactions at multiple scales, the importance of two aspects of palm leaf harvest to assessing the sustainability becomes clear: (1) palm harvest occurs in a landscape that is managed for multiple purposes in addition to leaf harvest, and (2) mountain date palm is involved in other plant-animal interactions that have the potential to both influence and be influenced by leaf harvest. These factors are likely applicable to many other NTFP species harvested from human-managed landscapes and must be considered when assessing the sustainability of NTFP harvest and developing management plans.

\section{Competing interests}

The authors declare that they have no competing interests.

\section{Authors' contributions}

LM participated in the design and coordination of the study, conducted harvester interviews, analyzed the results, and drafted the manuscript. Tा contributed to the design of the study and helped to draft the manuscript. SS provided harvest data from Karnataka and contributed to interpretation of the results. SN and AV provided harvest data from Tamil Nadu and contributed to interpretation of the results. All authors read and approved the final manuscript.

\section{Authors' information}

LM is currently a postdoctoral fellow with the Natural Capital Project at Stanford University and holds a PhD in Botany and a certificate in Ecology, Evolution and Conservation Biology from the University of Hawai'i at Mānoa. $\Pi T$ is Professor of Botany at the University of Hawai'i at Mānoa. SN is a founder and director of Keystone Foundation, working on eco-development program with indigenous people in the Western Ghats, India. She is Director of Programs at Keystone and the chairperson of the Non Timber Forest Produce Exchange Programme, a network of NGOs across South and Southeast Asia. SS is Fellow (scientist) in the Forest and Governance Program at the Ashoka Trust for Research in Ecology and the Environment (ATREE). AV has over 20 years of experience working in the Nilgiri Biosphere Reserve and helped build Keystone Foundation's conservation program. She has a Masters in Ecology and is currently pursuing a PhD in Botany at the University of Hawai'i at Mānoa as an East West Center Fellow, Botany in Action Fellow and member of the IUCN (International Union for Conservation of Nature).

\section{Acknowledgements}

We thank Pradheeps, Sudhakar, and Mahadesh for their assistance with interviews; many field assistants for help with data collection; Eileen Herring for help in the library; and three anonymous reviewers for useful feedback on a previous draft of this manuscript. We thank the Tamil Nadu and Karnataka Forest Departments, and local LAMPS and VFCs for their cooperation. This work was supported by a Schultes Award from the Society for Economic Botany and by a National Science Foundation Graduate Research Fellowship under Grant No. 0822443 to LM.

\section{Author details}

'Botany Department, University of Hawai'i at Mānoa, Mānoa, Hawai'i, USA. Ecology, Evolution and Conservation Biology Program, University of Hawai'i at Mānoa, Mānoa, Hawai'i, USA. ${ }^{3}$ Keystone Foundation, Kotagiri, Tamil Nadu, India. ${ }^{4}$ Ashoka Trust for Research in Ecology and the Environment, Bangalore, Karnataka, India. ${ }^{5}$ Current address: Natural Capital Project, Woods Institute for the Environment, Stanford University, Stanford, CA, USA

Received: 30 November 2012 Accepted: 10 May 2013

Published: 9 July 2013

\section{References}

Anten NPR, Ackerly DD, Martinez-Ramos M (2003) Defoliation and growth in an understory palm: quantifying the contributions of compensatory responses. Ecology 84:2905-2918
Barrow SC (1998) A monograph of Phoenix L. (Palmae: Coryphoideae). Kew Bull 53:513-575

Belcher B, Schreckenberg K (2007) Commercialisation of non-timber forest products: a reality check. Dev Policy Rev 25:355-377

Biswal R (2009) Exploring the contribution of NTFPs to rural livelihoods: the case of the Nilgiri Biosphere Reserve, India, Master's Thesis. University of East Anglia, UK

Blancas J, Casas A, Rangel-Landa S, Moreno-Calles A, Torres I, Pérez-Negrón E, Solís L, Delgado-Lemus A, Parra F, Yaaye A, Caballero J, Cortés L, Lira R, Dávila P (2010) Plant management in the Tehuacán-Cuicatlán Valley, Mexico. Econ Bot 64:287-302

Brummit N, Bachman S (2010) Plants under pressure-a global assessment: the first report of the IUCN sampled red list index for plants. Royal Botanic Gardens, Kew, UK

Cunningham SA (1997) The effect of light environment, leaf area, and stored carbohydrates on inflorescence production by a rain forest understory palm. Oecologia 111:36-44

Cunningham AB (2001) Applied ethnobotany: people, wild plant use, and conservation. Earthscan, London

Davidar P, Sahoo S, Mammen PC, Acharya P, Puyravaud J-P, Arjunan M, Garrigues JP, Roessingh K (2010) Assessing the extent and causes of forest degradation in India: where do we stand? Biol Conserv 143:2937-2944

Endress BA, Gorchov DL, Noble RB (2004) Non-timber forest product extraction: effects of harvest and browsing on an understory palm. Ecol Appl 14:1139-1153

Estes JA, Terborgh J, Brashares JS, Power ME, Berger J, Bond WJ, Carpenter SR, Essington TE, Holt RD, Jackson JBC, Marquis RJ, Oksanen L, Okansen T, Paine RT, Pikitch EK, Ripple WJ, Sandin SA, Scheffer M, Schoener TW, Shurin JB, Sinclair ARE, Soulé ME, Virtanen R, Wardle DA (2011) Trophic downgrading of planet earth. Science 333:301-306

Fuhlendorf SD, Engle DM, Kerby JAY, Hamilton R (2009) Pyric herbivory: rewilding landscapes through the recoupling of fire and grazing. Conserv Biol 23:588-598

Gaston KJ (2010) Valuing common species. Science 327:154-155

Gaston KJ, Fuller RA (2008) Commonness, population depletion and conservation biology. Trends Ecol Evol 23:14-19

Grime JP (1998) Benefits of plant diversity to ecosystems: immediate, filter and founder effects. J Ecol 86:902-910

International Monetary Fund (2012) World economic outlook database. http:// www.imf.org/external/pubs/ft/weo/2012/01/weodata/index.aspx. Accessed 13 June 2012

IUCN (International Union for Conservation of Nature) (2011) Red list of threatened species, version 2011.2. http://www.iucnredlist.org. Accessed 22 May 2012

Keystone Foundation (2007) Honey trails in the Blue Mountains: ecology, people and livelihood in the Nilgiri Biosphere Reserve, India. Coonoor Printing, Coonoor, India

Keystone Foundation (2009) Report on status of Village Forest Councils in the Nilgiri Biosphere Reserve_-International Development Research Centre case study. Keystone Foundation, Kotagiri, India

Kinnaird MF (1992) Competition for a forest palm: use of Phoenix reclinata by human and nonhuman primates. Conserv Biol 6:101-107

Leisher C, Sanjayan M, Blockhus J, Kontoleon A, Larsen SN (2010) Does conserving biodiversity work to reduce poverty? A state of knowledge review. The Nature Conservancy, Washington, DC

Mandle $L$ (2012) Balancing biodiversity and human land use: effects of fire, grazing and harvest on plant individuals, populations and communities in the Western Ghats, India, PhD Dissertation. University of Hawai'i at Mānoa, Mānoa, HI, USA

Mandle L, Ticktin T (2012) Interactions among fire, grazing, harvest and abiotic conditions shape palm demographic responses to disturbance. J Ecol 100:997-1008

Moegenburg SM, Levey DJ (2003) Do frugivores respond to fruit harvest? An experimental study of short-term responses. Ecology 84:2600-2612

Myers N, Mittermeier RA, Mittermeier CG, Da Fonseca GAB, Kent J (2000) Biodiversity hotspots for conservation priorities. Nature 403:853-858

Nath S (2000) Non timber forest products in the Nilgiris-a case for local resource management. Voices For 8:5-10

NREGA (2005) The National Rural Employment Guarantee Act, No. 42, New Delhi, India

O'Hara JL (1999) An ecosystem approach to monitoring non-timber forest products harvest: the case study of bayleaf palm (Sabal mauritiiformis) in the 
Rio Bravo conservation and management area, Belize, PhD Dissertation. Yale University, New Haven, CT, USA

Padmanabhan D, Sudhersan C (1988) Mass destruction of Phoenix loureirii in South India. Principes 32:118-123

Reid LA (2005) The effects of traditional harvesting practices on restored sweetgrass populations, Master's Thesis. State University of New York, Syracuse, NY, USA

Roveta RJ (2008) Traditional use of fire for the provision of ecosystem services: a case study in BRT Wildlife Sanctuary, Master's Thesis. University of Freiburg, Freiburg, Germany

Schmidt IB (2011) Effects of local ecological knowledge, harvest and fire on golden-grass (Syngonanthus nitens, Eriocaulaceae), a non-timber forest product (NTFP) species from the Brazilian savanna, PhD Dissertation. University of Hawai'i at Mānoa, Mānoa, HI, USA

Schmidt IB, Mandle L, Ticktin T, Gaoue OG (2011) What do matrix population models reveal about the sustainability of non-timber forest product harvest? J Appl Ecol 48:815-826

Shaanker RU, Ganeshaiah KN, Krishnan S, Ramya R, Meera C, Aravind NA, Kumar A, Rao D, Vanaraj G, Ramachandra J, Gauthier R, Ghazoul J, Poole N, Reddy BVC (2004) Livelihood gains and ecological costs of non-timber forest product dependence: assessing the roles of dependence, ecological knowledge and market structure in three contrasting human and ecological settings in South India. Environ Conserv 31:242-253

Shackleton SE (2005) The significance of the local trade in natural resource products for livelihoods and poverty alleviation in South Africa, PhD Dissertation. Rhodes University, Grahamstown, South Africa

Shackleton CM, Parkin F, Chauke MI, Downsborough L, Oslen A, Brill G, Weideman C (2009) Conservation, commercialisation and confusion: harvesting of Ischyrolepis in a coastal forest, South Africa. Environ Dev Sustain 11:229-240

Shankar U, Hegde R, Bawa KS (1998) Extraction of non-timber forest products in the forests of Biligiri Rangan Hills, India. 6. Fuelwood pressure and management options. Econ Bot 52:320-336

Sukumar R (1990) Ecology of the Asian elephant in southern India. II. Feeding habits and crop raiding patterns. J Trop Ecol 6:33-53

Sundaram B, Hiremath AJ (2012) Lantana camara invasion in a heterogeneous landscape: patterns of spread and correlation with changes in native vegetation. Biol Invasions 14:1127-1141

Sundararaj DD, Balasubramanyam G (1986) Guide to the economic plants of South India. Periodical Expert Book Agency, Delhi, India

Ticktin T (2004) The ecological implications of harvesting non-timber forest products. J Appl Ecol 41:11-21

Ticktin T, Nantel P (2004) Dynamics of harvested populations of the tropical understory herb Aechmea magdalenae in old-growth versus secondary forests. Biol Conserv 120:461-470

Varghese A, Ticktin T (2008) Regional variation in non-timber forest product harvest strategies, trade, and ecological impacts: the case of black dammar (Canarium strictum Roxb.) use and conservation in the Nilgiri Biosphere Reserve, India. Ecol Soc 13:11

Zuidema PAA, De Kroon H, Werger MJA (2007) Testing sustainability by prospective and retrospective demographic analyses: Evaluation for palm leaf harvest. Ecol Appl 17:118-128

doi:10.1186/2192-1709-2-21

Cite this article as: Mandle et al:: A framework for considering ecological interactions for common non-timber forest product species: a case study of mountain date palm (Phoenix loureiroi Kunth) leaf harvest in South India. Ecological Processes 2013 2:21.

\section{Submit your manuscript to a SpringerOpen ${ }^{\odot}$ journal and benefit from:}

- Convenient online submission

- Rigorous peer review

- Immediate publication on acceptance

- Open access: articles freely available online

- High visibility within the field

- Retaining the copyright to your article

Submit your next manuscript at $\gg$ springeropen.com 